\title{
The Insertion of Fluorescent Proteins in a Variable Region of Respiratory Syncytial Virus L Polymerase Results in Fluorescent and Functional Enzymes But with Reduced Activities
}

\author{
Jenna Fix, Marie Galloux, Marie-Lise Blondot, and Jean-François Eléouët*
}

INRA, Unité de Virologie Immunologie Moléculaires UR892, F-78350 Jouy-en-Josas, France

\begin{abstract}
The respiratory syncytial virus (RSV) Large protein L is the catalytic subunit of the RNA-dependent RNA polymerase complex. Currently, no structural information is available for RSV L. Sequence alignments of L protein from human and bovine strains of RSV revealed the existence of two variable regions, VR1 and VR2. Following comparison with morbillivirus and rhabdovirus L genes, VR2, which is located between domains V and VI, was chosen as an insertion site for sequences encoding the epitope tag HA or the fluorescent proteins eGFP and mCherry. Recombinant tagged-L proteins co-localized with RSV N and P proteins in transfected cells. These recombinant polymerases were shown to be functional using a viral minigenome system assay, their activities being reduced by $\sim 70 \%$ compared to the unmodified $\mathrm{L}$ polymerase. We have also shown by site-directed mutagenesis that the GDNQ motif (residues 810-813 for the Long strain of HRSV) is essential for L activity.
\end{abstract}

Keywords: Respiratory syncytial virus, L protein, RNA-dependent RNA polymerase, HA tag, eGFP, mCherry.

Human and bovine respiratory syncytial viruses (HRSV and BRSV) are two closely related, highly infectious, worldwide prevalent viruses that are the leading cause of acute lower respiratory tract disease in children and calves, respectively [1]. RSV is a negative strand RNA virus that belongs to the Pneumovirus genus within the Paramyxoviridae family. The $15 \mathrm{~kb}$ negative-strand genomic RNA is encapsidated by the nucleoprotein $(\mathrm{N})$ forming a ribonucleoprotein complex (RNP) which is the template for the viral RNA-dependent RNA polymerase (RdRp) complex [2]. The RdRp minimum complex is composed of the large catalytic subunit $\mathrm{L}$ and its cofactor the phosphoprotein $\mathrm{P}$. The replicase activity also requires $\mathrm{N}$, while efficient transcriptase activity needs the M2-1 anti-termination factor [3]. Cell infection by RSV induces the formation of cytoplasmic inclusion bodies [4] containing N, P, M2-1, L, the matrix protein $(\mathrm{M})$, the non-structural protein 2 (NS2), low amounts of the small hydrophobic SH protein, viral RNA, and the cellular proteins Hsp70 and actin [5-12]. In rhabdovirus-infected cells, inclusion bodies were shown to be sites of viral RNA synthesis $[13,14]$. For this reason, it is thought that these structures are likely to be sites of replication and/or transcription for RSV [15]. Until recently, detection of RSV L in cells has been hampered by the lack of suitable antibodies [9].

As for all of the polymerases of non-segmented negativestranded viruses (NNSV), the L of RSV is believed to perform all of the catalytic functions, e.g. RNA synthesis, capping, methylation and polyadenylation $[16,17]$. Analysis of the primary sequences of $L$ revealed the presence of six

*Address correspondence to this author at the INRA, Unité de Virologie Immunologie Moléculaires UR892, F-78350 Jouy-en-Josas, France; Tel: (33) 1346526 04; Fax: (33) 134652621 ;

E-mail: jean-francois.eleouet@jouy.inra.fr blocks of conserved regions (CRs I-VI) shared among all Mononegavirales L proteins [16]. Recent structural studies of the L encoded by the rhabdovirus vesicular stomatitis virus (VSV) have shown that these CRs correspond to physical distinct functional domains, domains I-IV forming a ring domain, and domains V-VI forming an appendage of three globular domains [18]. A polymerase signature motif GDNQ, which is thought to be the active site for phosphodiester bond formation, lies in the CR III (residues 810-813) of the HRSV Long strain [17].

Sequence alignments of Morbillivirus (also members of the Paramyxoviridae family) L proteins revealed three conserved domains (D1, D2, D3) separated by two highly variable regions termed "hinges» $\mathrm{H} 1$ and $\mathrm{H} 2$ [19]. It was shown that insertion of eGFP in the second hinge (H2) had an attenuation effect on the virus replication but did not abolish the polymerase activity $[19,20]$. However, the sequence of L RSV doesn't share enough sequence homology with those of the Morbilliviruses L proteins to assign equivalent domains.

To obtain preliminary data on the organization of the RSV L protein, we aligned $\mathrm{L}$ sequences from human RSV (HRSV) and bovine RSV (BRSV) strains and found that these L proteins are highly conserved except for two highly variable regions, that we designated VR1 and VR2 (Fig. 1A). The VR2 region includes residues 1717 to 1764 in human RSV Long strain and is located between CRs V and VI, which contain putative capping and cap methylation activities, respectively. We investigated whether the RSV L VR2 region could tolerate sequence insertions, as has been previously shown for morbilliviruses. In this study, we used plasmids $\mathrm{pN}, \mathrm{pP}, \mathrm{pM} 2-1$ and $\mathrm{pL}$ coding for HRSV (strain Long) N, P, M2-1 and L proteins, respectively, under the control of the T7 promoter [21]. An encephalomyocarditis 
(A) HRSV L protein

VR1

(137-184)

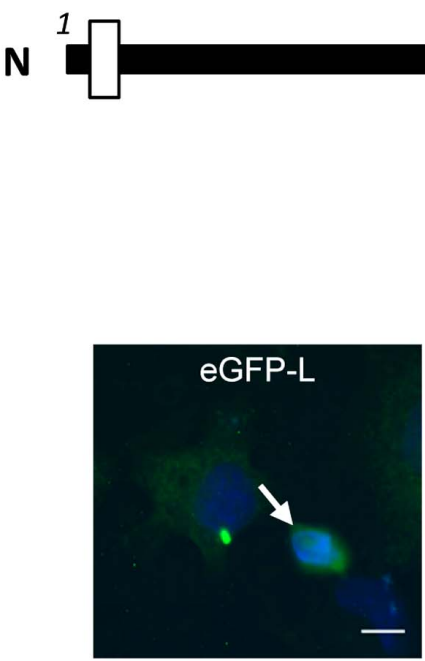

VR2

(1718-1764)

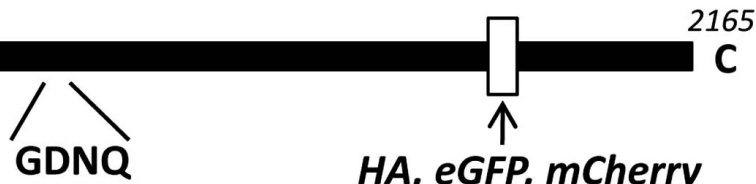

(1738-1739)
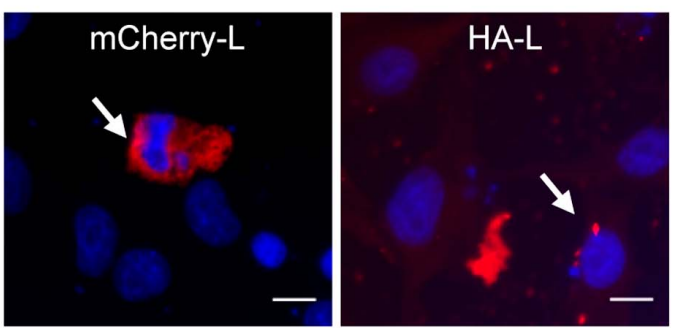

(810-813)

(B)

(C)

modified $L$ protein $+\mathbf{P}$
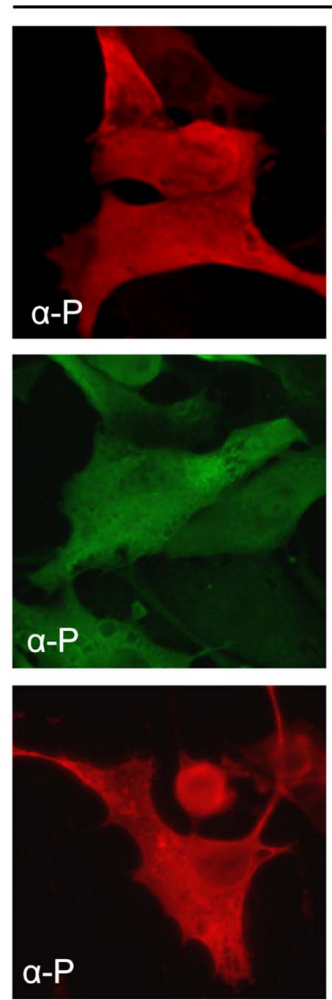
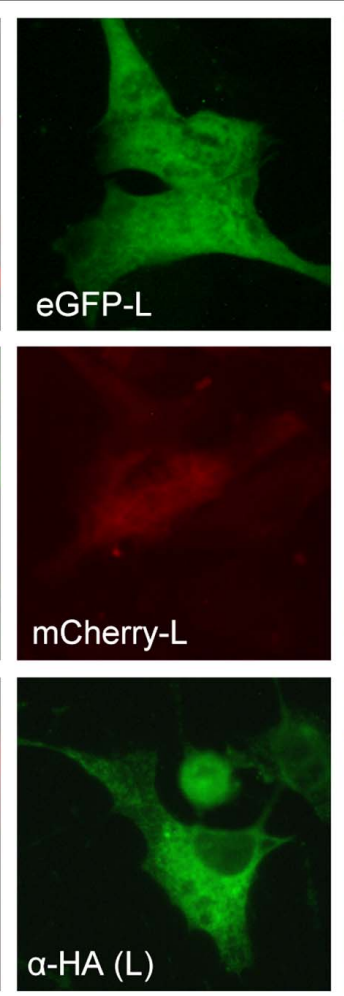
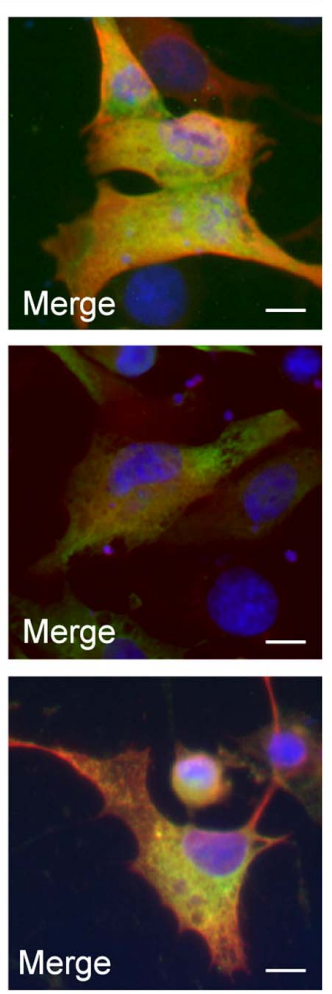

P alone

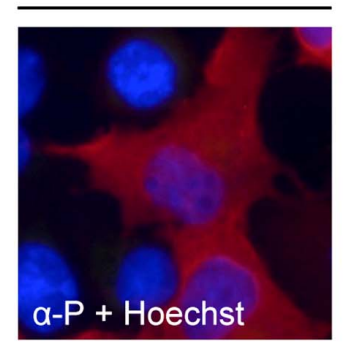

a-P + Hoechst

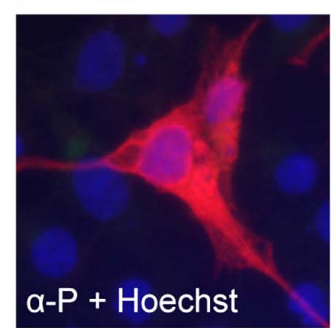

Fig. (1). Expression of tagged L polymerases. (A) Schematic representation of the RSV L polymerase showing the two variable regions VR1 and VR2 (open boxes) identified after amino acid sequence alignments of the L protein of BRSV (strain ATue51908; accession number NC_001989.1) and HRSV (strain Long; accession number P28887.1). A Sall site was generated within the VR2 region by site directed mutagenesis and used for insertion of either an HA tag, eGFP or mCherry ORFs between L amino acid residues 1738 and 1739 (arrow). The GDNQ catalytic site of HRSV L is indicated. Amino acid positions are given in parenthesis. (B) Expression of eGFP-L, mCherry-L, and HAL polymerase alone in BSRT7/5 cells. Arrows indicate cells expressing L-tagged proteins, which present condensed nuclei. (C) Coexpression of L-tagged polymerases with P. Cells were fixed $24 \mathrm{~h}$ post transfection. eGFP and mCherry were visualized by virtue of their own fluorescence, HA-L was labeled with anti-HA antibodies (green), and P with anti-P antiserum (red or green). Nuclei were stained with Hoechst 33342 and are shown in the merged pictures. Scale bars, $10 \mu \mathrm{m}$. 
virus internal ribosome entry site (IRES) sequence was placed between the $\mathrm{T} 7$ promoter and the inserted ORF to enhance protein expression in BSR/T7-5 cells, a BHK21 clone stably expressing T7 RNA polymerase [22], as previously described [23]. We introduced a unique restriction enzyme site at nucleotide 5212 of the $\mathrm{L}$ gene in the T7 polymerase-driven expression $\mathrm{pL}$ vector, by site directed mutagenesis (Quickchange, Stratagene). Codons 1738 and 1739 (GTT GAC) were substituted with GTC GAC, creating a Sall site without any change in the L amino acid sequence. We then generated three $\mathrm{L}$ protein expression plasmids, pHA-L, pmCherry-L and peGFP-L, encoding the $\mathrm{L}$ protein tagged with an HA epitope (42 bp), mCherry (Clontech, 708 bp), and eGFP (Clontech, 718 bp), respectively. To do so, complementary oligonucleotides encoding a HA tag epitope (sequences available on request) were annealed to generate SalI-compatible ends. The resulting fragment was inserted into the SalI restriction site present in VR2 in frame with the L sequence. EGFP and mCherry genes were amplified by standard techniques and cloned in-frame into the SalI site of VR2.

The expression of HA-L, mCherry-L and eGFP-L and their ability to co-localize with RSV P and N proteins in cells was analyzed by fluorescence microscopy. BSR/T7-5 cells grown on coverslips in 24 well plates were independently transfected either with $0.4 \mu \mathrm{g}$ of pHA-L, pmCherry-L, or peGFP-L vector alone, or together with 0.3 $\mu \mathrm{g}$ of $\mathrm{pP}$, or $0.1 \mu \mathrm{g}$ of $\mathrm{pN}$, or with both $\mathrm{pP}$ and $\mathrm{pN}$, using Lipofectamine 2000 (Invitrogen). Twenty four hours posttransfection cells were fixed with $4 \%$ paraformaldehyde in PBS for $30 \mathrm{~min}$, permeabilized for 5 min with $0.1 \%$ Triton $\mathrm{X}-100$ and $0.5 \%$ BSA in PBS and incubated for $1 \mathrm{~h}$ at room temperature with the primary antibodies diluted $1: 100$ in PBS. For HA-L, we used a mouse anti-HA monoclonal antibody (Sigma, clone HA-7), a rabbit anti-P antiserum previously described [24] and a mouse anti-N (Serotec) for P and $\mathrm{N}$ labeling, respectively. Cells were then washed with PBS and incubated for an additional hour with either FITCconjugated sheep anti-mouse (P.A.R.I.S), Alexa Fluor-488 goat anti-rabbit, Alexa Fluor-594 rabbit anti-mouse, or Alexa594 goat anti-rabbit (Invitrogen) IgG, depending of the presence of eGFP- or mCherry- recombinant L constructs. Nuclei were stained with Hoechst 33342 (Invitrogen). Cells were observed with a Nikon TE200 microscope and images were processed using MetaVue software (Molecular Devices). When HA-L, eGFP-L, and mCherry-L were expressed alone, no or very low levels of fluorescence were observed except in a few cells that were showing an apoptotic phenotype, i.e. rounded cells with condensed nuclei (Fig. 1B). Similar results were obtained when the various recombinant $\mathrm{L}$ constructs were co-expressed with $\mathrm{N}$ in the absence of $\mathrm{P}$ (data not shown). These results suggest that when expressed alone or with $\mathrm{N}$, the $\mathrm{L}$ protein is toxic to the cells. Interestingly, when $P$ was co-transfected with each L construct, a low but specific fluorescence level was observed in the cytoplasm of HA-L, eGFP-L and mCherry-L transfected cells (Fig. 1C). Although co-localization of P and $\mathrm{L}$ within the cytoplasm was not clear, these results indicate that co-expression of $\mathrm{P}$ together with $\mathrm{L}$ in the absence of other RSV proteins may stabilize L or render it less toxic to the cells. Indeed, it was previously shown that the presence of P induces VSV L rearrangements, the formation of VSV L dimers [18] and seems to stabilize VSV L $[25,26]$.

Fig. (2B) shows co-expression of HA-L, eGFP-L or LmCherry together with $\mathrm{P}$ and $\mathrm{N}$, which resulted in the formation of cytoplasmic inclusions bodies containing $\mathrm{L}, \mathrm{N}$ and $\mathrm{P}$, that were similar to those observed in RSV-infected cells (Fig. 2C) [9]. The computer-generated merged images showed yellow patches, indicative of co-localization of $\mathrm{L}$ and P. Co-transfection of BSRT7/5 cells with $\mathrm{pP}$ and $\mathrm{pN}$ in the absence of $\mathrm{L}$ also induced cytoplasmic inclusions bodies containing both $\mathrm{P}$ and $\mathrm{N}$ (Fig. 2A). This is consistent with previous studies [5]. To compare structures seen inside transfected cells with those seen during virus infection, HEp2 cells were infected with hRSV, fixed $24 \mathrm{~h}$ after infection and stained with anti-N and anti-P antibodies. As shown in Fig. (2C), $\mathrm{P}$ and $\mathrm{N}$ co-localized in cytoplasmic inclusion bodies similar to those observed in BSRT7 co-transfected with $\mathrm{pN}$ and $\mathrm{pP}$. Taken together our data show that BSRT7/5 cells transfected with $\mathrm{pN}$ and $\mathrm{pP}$ form cytoplasmic inclusion bodies that are morphologically indistinguishable from those seen in virus infected cells. Moreover transfection of plasmids coding for $\mathrm{L}$ proteins harboring short (HA tag) or longer (mCherry and eGFP) in-frame insertions in their VR2 region resulted in the expression of tagged $\mathrm{L}$ proteins that can interact with the RSV N and P proteins, leading to their incorporation in those cytoplasmic inclusion bodies.

Finally, the activity of HA-L, mCherry-L and eGFP-L modified polymerases was assessed using an RSV minigenome encoding a luciferase (LUC) reporter gene. As residues $\mathrm{D}$ and $\mathrm{N}$ in the GDNQ motif within the $\mathrm{L}$ gene of Rinderpest virus were previously demonstrated to be critically important [27], we changed the putative catalytic site GDNQ motif (residues 810-813) of the RSV L protein to GDDQ and GDQQ in the pHA-L vector, using site-directed mutagenesis (Quickchange, Stratagene) in order to generate an inactive L protein. BSR/T7-5 cells in 24 well plates were co-transfected with $0.5 \mu \mathrm{g}$ of $\mathrm{pM} / \mathrm{Luc}$ encoding the RSV minigenome containing the firefly LUC reporter gene [21], $0.25 \mu \mathrm{g}$ of $\mathrm{pRSV}-\beta-\mathrm{Gal}$ (Promega) to normalize transfection efficiencies, $0.5 \mu \mathrm{g}$ of $\mathrm{pN}, 0.5 \mu \mathrm{g}$ of $\mathrm{pP}, 0.5 \mu \mathrm{g}$ of pM2-1 and increasing amounts of one of the $\mathrm{L}$ expression plasmids, peGFP-L, pmCherry-L, pHA-L, pHA-L ${ }^{\mathrm{N} 812 \mathrm{D}}$, pHA-L ${ }^{\mathrm{N} 812 \mathrm{Q}}$, or $\mathrm{pL}$ encoding the wild-type polymerase (wt L). Cells were harvested $24 \mathrm{~h}$ post-transfection, lyzed in $100 \mu \mathrm{l}$ of luciferase lysis buffer (30 mM Tris $\mathrm{pH} 7.9,10 \mathrm{mM} \mathrm{MgCl} 2,1 \mathrm{mM}$ DTT, $1 \%(\mathrm{v} / \mathrm{v})$ Triton $\mathrm{X}-100$, and $15 \%(\mathrm{v} / \mathrm{v})$ glycerol), and luciferase (LUC) activity was determined twice for each cell lysate $(40 \mu \mathrm{l})$ with an Anthos Lucy 3 luminometer (Bio Advance). LUC activities were normalized based on $\beta$ galactosidase expression. Transfections were done in triplicates. As shown on Fig. (3A), maximum levels of LUC activity were obtained when $250 \mathrm{ng}$ of wt $\mathrm{L}$ expressing plasmid was used for the transfection. The three constructs HA-L, mCherry-L and eGFP-L presented an RNA polymerase activity, as demonstrated by LUC activity, but with relative activities of about $30 \%$ of the wt L. No activity was detected for $\mathrm{L}^{\mathrm{N} 812 \mathrm{Q}}$ and $\mathrm{L}^{\mathrm{N} 812 \mathrm{D}}$ although both were still able to co-localize with $\mathrm{P}$ and $\mathrm{N}$ in cells (Fig. 3B). These results demonstrate that, as has been shown for morbilliviruses $[19,20]$ and rhabdoviruses [28], the pneumovirus RSV L can tolerate a large insertion of $11 \%$ within its coding sequence. 


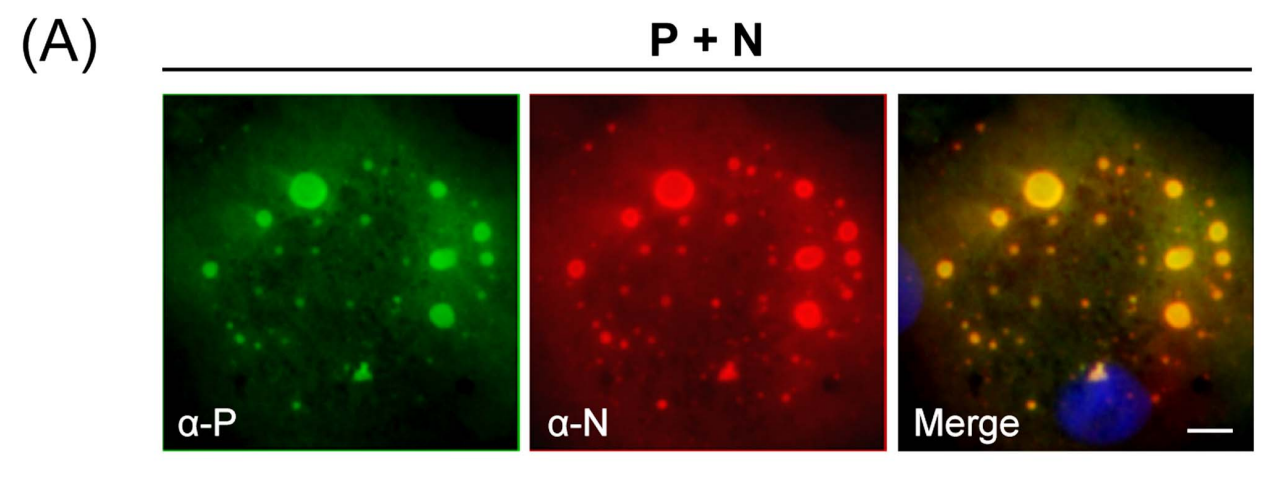

(B)

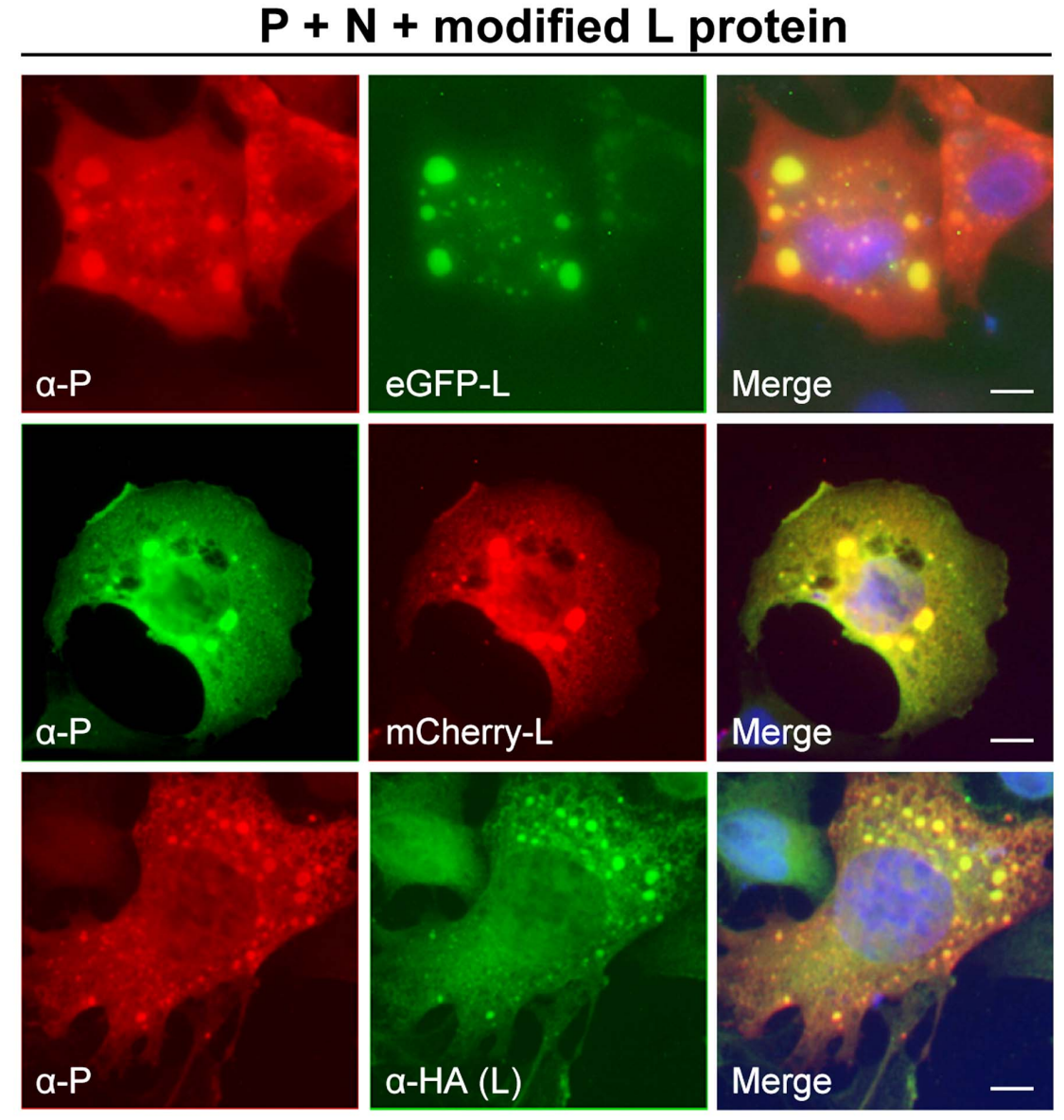

(C)
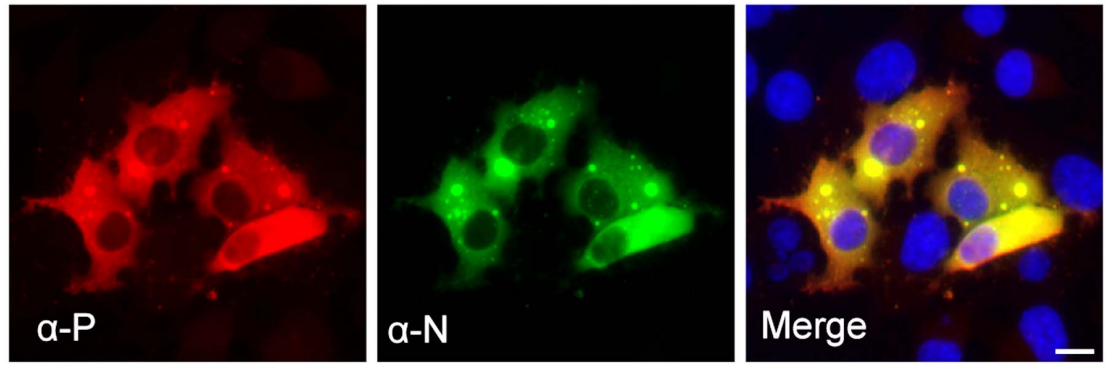

Fig. (2). HA-L, eGFP-L and mCherry-L co-localize with inclusion bodies formed by $\mathrm{P}$ and $\mathrm{N}$ in the absence of other viral proteins. Coexpression of P and N (A) or of HA-L, eGFP-L and mCherry-L together with P and N (B) in BSRT7/5 cells. (C) Hep-2 cells infected by HRSV (strain Long) $24 \mathrm{~h}$ post infection. Cells were fixed $24 \mathrm{~h}$ post transfection (A, B) or post infection (C) and labeled with anti-P antibodies (green or red) together with either anti-N (red) or anti-HA (green) antibodies, and the distribution of viral proteins was observed by fluorescence microscopy. eGFP and mCherry were visualized by virtue of their own fluorescence. The yellow color present on computergenerated merges denotes co-localization. Nuclei are in blue ( stained with Hoechst 33342). Scale bars, $10 \mu \mathrm{m}$. 
(a)

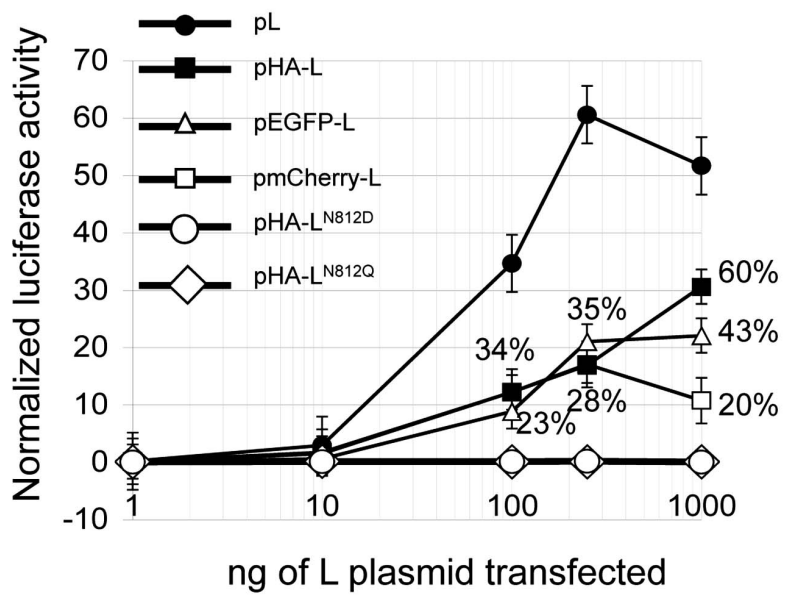

(b)
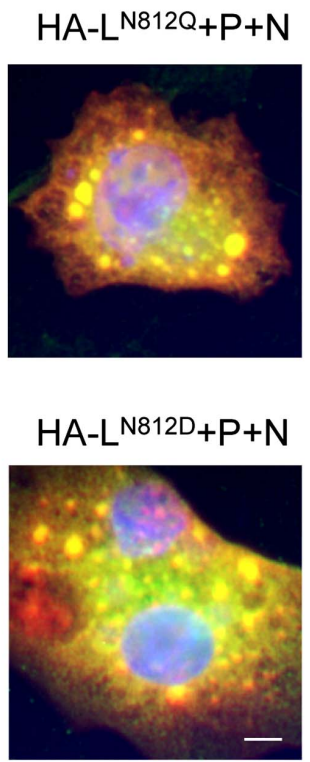

Fig. (3). Activity of tagged L polymerases. (A) Relative activities of wild type, HA-, mCherry-, eGFP-tagged and N812Q and N812D mutant HA-tagged L polymerases in a series of minigenome rescue experiments. Various amounts of pL (filled circles), pHA-L (crosses), pmCherry-L (open squares), peGFP-L (open triangles), and pHA-L ${ }^{\mathrm{N} 812 \mathrm{D}}$ (open circles) or pHA-L ${ }^{\mathrm{N} 812 \mathrm{Q}}$ (filled diamonds) were used in minigenome transfection assays. Each luciferase minigenome activity value was normalized $24 \mathrm{~h}$ after transfection based on $\beta$-galactosidase expression and is the average of three independent experiments assayed in triplicate. The indicated percentages represent the relative activity of the structurally modified RdRp compared to the wild type control. Error bars denote standard deviations. (B) HA-L ${ }^{\mathrm{N} 812 \mathrm{Q}}$ and $\mathrm{HA}-\mathrm{L}^{\mathrm{N} 812 \mathrm{D}}$

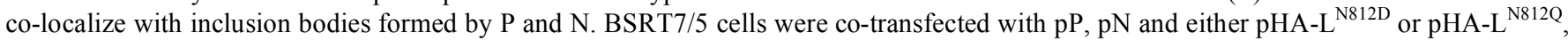
fixed and labeled with anti-P (red) and anti-HA (green) antibodies as described in the Fig. (1) legend.

In conclusion, we have demonstrated that i) the GDNQ motif (residues 810-813) of the pneumovirus RSV L protein is critical for its activity, and ii) the L polymerase contains a variable region (VR2) that can be used to tag the $\mathrm{L}$ protein in order to track it in living cells. The VR2 region is localized between CRs V and VI of $\mathrm{L}$ and is equivalent to the $\mathrm{H} 2$ hinge region previously identified for paramyxovirus and rhabdovirus L proteins. Insertion of short (HA) or longer sequences (eGFP and mCherry) within this region creates functional RdRp but with reduced activities (roughly $30 \%$ of the unmodified L). These tagged L proteins constitute a useful and valuable tool and open up a number of avenues for studies of RSV L trafficking and function in living cells. Furthermore, using reverse genetics to insert these mutations into virus may prove to be an effective means to rationally attenuate RSV with the potential to produce RSV strains suitable for use as a vaccine.

\section{ACKNOWLEDGEMENTS}

We thank Nathalie Castagné for technical help, Michel Brémont, Stéphane Biacchesi, and David Bhella for critical reading of the manuscript.

\section{REFERENCES}

[1] Collins PL, Crowe JE. Respiratory Syncytial Virus and Metapneumovirus. In Fields Virology. $5^{\text {th }}$ ed. Knipe DM, Howley PM, Eds. Philadelphia: Lippincott Williams \& Wilkins 2007; pp. 1601-46.

[2] Cowton VM, McGivern DR, Fearns R. Unravelling the complexities of respiratory syncytial virus RNA synthesis. J Gen Virol 2006; 87(Pt 7): 1805-21.

[3] Collins PL, Hill MG, Camargo E, Grosfeld H, Chanock RM, Murphy BR. Production of infectious human respiratory syncytial virus from cloned cDNA confirms an essential role for the transcription elongation factor from the 5 ' proximal open reading frame of the M2 mRNA in gene expression and provides a capability for vaccine development. Proc Natl Acad Sci USA 1995; 92(25): 11563-7.

[4] Norrby E, Marusyk H, Orvell C. Morphogenesis of respiratory syncytial virus in a green monkey kidney cell line (Vero). J Virol 1970; 6(2): 237-42.

[5] Garcia J, Garcia-Barreno B, Vivo A, Melero JA. Cytoplasmic inclusions of respiratory syncytial virus-infected cells: formation of inclusion bodies in transfected cells that coexpress the nucleoprotein, the phosphoprotein, and the $22 \mathrm{~K}$ protein. Virology 1993; 195(1): 243-7.

[6] Ghildyal R, Mills J, Murray M, Vardaxis N, Meanger J. Respiratory syncytial virus matrix protein associates with nucleocapsids in infected cells. J Gen Virol 2002; 83(Pt 4): 753-7.

[7] Rixon HW, Brown G, Aitken J, McDonald T, Graham S, Sugrue RJ. The small hydrophobic ( $\mathrm{SH}$ ) protein accumulates within lipidraft structures of the Golgi complex during respiratory syncytial virus infection. J Gen Virol 2004; 85(Pt 5): 1153-65.

[8] Brown G, Rixon HW, Steel J, et al. Evidence for an association between heat shock protein 70 and the respiratory syncytial virus polymerase complex within lipid-raft membranes during virus infection. Virology 2005; 338(1): 69-80.

[9] Carromeu C, Simabuco FM, Tamura RE, Farinha Arcieri LE, Ventura AM. Intracellular localization of human respiratory syncytial virus L protein. Arch Virol 2007; 152(12): 2259-63.

[10] Jeffree CE, Brown G, Aitken J, Su-Yin DY, Tan BH, Sugrue RJ. Ultrastructural analysis of the interaction between F-actin and respiratory syncytial virus during virus assembly. Virology 2007; 369(2): 309-23.

[11] Li D, Jans DA, Bardin PG, Meanger J, Mills J, Ghildyal R. Association of respiratory syncytial virus $M$ protein with viral nucleocapsids is mediated by the M2-1 protein. J Virol 2008; 82(17): 8863-70.

[12] Lindquist ME, Lifland AW, Utley TJ, Santangelo PJ, Crowe JE, Jr. Respiratory syncytial virus induces host RNA stress granules to facilitate viral replication. J Virol 2010; 84(23): 12274-84. 
[13] Lahaye X, Vidy A, Pomier C, et al. Functional characterization of Negri bodies (NBs) in rabies virus-infected cells: Evidence that NBs are sites of viral transcription and replication. J Virol 2009; 83(16): 7948-58.

[14] Heinrich BS, Cureton DK, Rahmeh AA, Whelan SP. Protein expression redirects vesicular stomatitis virus RNA synthesis to cytoplasmic inclusions. PLoS Pathog 2010; 6(6): e1000958.

[15] Santangelo P, Nitin N, LaConte L, Woolums A, Bao G. Live-cell characterization and analysis of a clinical isolate of bovine respiratory syncytial virus, using molecular beacons. J Virol 2006; 80(2): 682-8.

[16] Poch O, Blumberg BM, Bougueleret L, Tordo N. Sequence comparison of five polymerases ( $\mathrm{L}$ proteins) of unsegmented negative-strand RNA viruses: theoretical assignment of functional domains. J Gen Virol 1990; 71 ( Pt 5): 1153-62.

[17] Stec DS, Hill MG, 3rd, Collins PL. Sequence analysis of the polymerase L gene of human respiratory syncytial virus and predicted phylogeny of nonsegmented negative-strand viruses. Virology 1991; 183(1): 273-87.

[18] Rahmeh AA, Schenk AD, Danek EI, et al. Molecular architecture of the vesicular stomatitis virus RNA polymerase. Proc Natl Acad Sci USA 2010; 107(46): 20075-80.

[19] Duprex WP, Collins FM, Rima BK. Modulating the function of the measles virus RNA-dependent RNA polymerase by insertion of green fluorescent protein into the open reading frame. J Virol 2002; 76(14): 7322-8.

[20] Brown DD, Rima BK, Allen IV, et al. Rational attenuation of a morbillivirus by modulating the activity of the RNA-dependent RNA polymerase. J Virol 2005; 79(22): 14330-8

[21] Tran TL, Castagne N, Dubosclard V, et al. The respiratory syncytial virus M2-1 protein forms tetramers and interacts with
RNA and P in a competitive manner. J Virol 2009; 83(13): 636374.

[22] Buchholz UJ, Finke S, Conzelmann KK. Generation of bovine respiratory syncytial virus (BRSV) from cDNA: BRSV NS2 is not essential for virus replication in tissue culture, and the human RSV leader region acts as a functional BRSV genome promoter. J Virol 1999; 73(1): 251-9.

[23] Jin H, Clarke D, Zhou HZ, et al. Recombinant human respiratory syncytial virus (RSV) from cDNA and construction of subgroup A and B chimeric RSV. Virology 1998; 251(1): 206-14.

[24] Castagne N, Barbier A, Bernard J, et al. Biochemical characterization of the respiratory syncytial virus P-P and P-N protein complexes and localization of the $\mathrm{P}$ protein oligomerization domain. J Gen Virol 2004; 85(Pt 6): 1643-53.

[25] Canter DM, Jackson RL, Perrault J. Faithful and efficient in vitro reconstitution of vesicular stomatitis virus transcription using plasmid-encoded L and P proteins. Virology 1993; 194(2): 518-29.

[26] Canter DM, Perrault J. Stabilization of vesicular stomatitis virus L polymerase protein by $\mathrm{P}$ protein binding: a small deletion in the $\mathrm{C}$ terminal domain of L abrogates binding. Virology 1996; 219(2): 376-86.

[27] Chattopadhyay A, Raha T, Shaila MS. Effect of single amino acid mutations in the conserved GDNQ motif of L protein of Rinderpest virus on RNA synthesis in vitro and in vivo. Virus Res 2004; 99(2): $139-45$.

[28] Ruedas JB, Perrault J. Insertion of enhanced green fluorescent protein in a hinge region of vesicular stomatitis virus $L$ polymerase protein creates a temperature-sensitive virus that displays no virionassociated polymerase activity in vitro. J Virol 2009; 83(23): 12241-52.

(C) Fix et al.; Licensee Bentham Open.

This is an open access article licensed under the terms of the Creative Commons Attribution Non-Commercial License (http: //creativecommons.org/licenses/by-nc/ $3.0 /$ ) which permits unrestricted, non-commercial use, distribution and reproduction in any medium, provided the work is properly cited. 